Editors' Note: Dr. Sundal discusses hereditary diffuse leukoencephalopathy with spheroids. Dr. Antezana et al. report a case of glatiramer acetate (GA)-induced hepatotoxicity and question whether liver function should be monitored in all patients initiated on GA. In reference to "Teaching Neurolmages: Microvascular decompression of the optic nerve," Dr. Ghuman and authors Woodall and Alleyne discuss the diagnosis of idiopathic intracranial hypertension in monocular vision loss.

-Megan Alcauskas, MD, and Robert C. Griggs, MD

\section{MICROGLIA: MULTIPLE ROLES IN SURVEILLANCE, CIRCUIT SHAPING, AND RESPONSE TO INJURY}

Christina Sundal, Gothenburg, Sweden: Dr. Benarroch ${ }^{1}$ provided an excellent overview of the role of microglia. Microglia are implicated in many neurodegenerative disorders and we noted that the newly identified colony stimulating factor 1 receptor $(C S F 1 R)$ gene mutation is causative for hereditary diffuse leukoencephalopathy with spheroids (HDLS). ${ }^{2}$ HDLS is an inherited progressive disorder of axons and myelin with a variable phenotype, mimicking other disorders such as primary progressive multiple sclerosis, frontotemporal dementia, other dementias and atypical parkinsonian disorders. ${ }^{2,3}$ The CSF1R gene encodes a tyrosine kinase transmembrane receptor for the cytokine CSF1, which is trophic for phagocytic cells of the myeloid lineage including microglia, and for interleukin 34 (IL-34). ${ }^{4}$ It has been established that lipid-laden microglia are a consistent microscopic finding in HDLS pathology. The CSF1R gene mutation thus establishes HDLS as a microgliopathy. ${ }^{2}$ However, the exact mechanism is unclear. It may be related to an abnormal innate immune response predisposing to neurodegeneration. Discovering the role of CSF1R signaling in HDLS might offer novel insights into microglial physiology and the involvement of this cell type in neurodegeneration.

(C) 2014 American Academy of Neurology

1. Benarroch EE. Microglia: multiple roles in surveillance, circuit shaping, and response to injury. Neurology 2013;81: 1079-1088.

2. Rademakers R, Baker M, Nicholson AM, et al. Mutations in the colony stimulating factor 1 receptor (CSF1R) gene cause hereditary diffuse leukoencephalopathy with spheroids. Nat Genet 2012;44:200-205.

3. Sundal C, Lash J, Aasly J, et al. Hereditary diffuse leukoencephalopathy with axonal spheroids (HDLS): a misdiagnosed disease entity. J Neurol Sci 2012;314:130-137.

4. Zelante T, Ricciardi-Castagnoli P. The yin-yang nature of CSF1R-binding cytokines. Nat Immunol 2012;13: 717-719.

\section{GLATIRAMER ACETATE-INDUCED ACUTE} HEPATOTOXICITY IN AN ADOLESCENT WITH MS Ariel Antezana, Joseph Herbert, James Park, Ilya Kister, New York: Similar to Makhani et al., ${ }^{1}$ we saw a case of glatiramer acetate (GA)-induced hepatotoxicity with no history of interferon exposure. A 28-year-old woman with multiple sclerosis developed jaundice, choluria, acholia, elevated aspartate aminotransferase/alanine aminotransferase $(905 / 1,103 \mathrm{U} / \mathrm{L})$ and direct and total bilirubin (4.3/8 mg/dL) after 6 months of GA therapy. Viral and autoimmune hepatitis serologies were negative. Liver biopsy revealed hepatocellular necrosis of zone 3 with portal bridging and portal lymphocytic inflammation consistent with medication-induced hepatocellular injury. Thirty days after GA was discontinued, liver function normalized. Natalizumab was initiated and tolerated without complications for more than a year.

The US Food and Drug Administration Adverse Event Reporting System database contains 95 reports of liver injury suspected to be a result of GA, including 51 cases in which GA was the only medication administered. ${ }^{2}$ The mechanism of hepatotoxicity is unclear as GA is not known to be metabolized in the liver.

Although GA was not found to cause hepatotoxicity in clinical trials, these cases ${ }^{1,3-5}$ raise the question of whether liver function should be monitored in patients who are initiated on GA. It seems prudent to inform patients about symptoms of hepatotoxicity and advise them to seek immediate attention if these symptoms develop.

(C) 2014 American Academy of Neurology

1. Makhani N, Ngan BY, Kamath BM, Yeh EA. Glatiramer acetate-induced acute hepatotoxicity in an adolescent with MS. Neurology 2013;81:850-852. 


\section{Neurology}

\section{Microglia: Multiple roles in surveillance, circuit shaping, and response to injury}

Christina Sundal

Neurology 2014;82;1846

DOI 10.1212/WNL.0000000000000399

\section{This information is current as of May 19, 2014}

\section{Updated Information \& Services}

References

Permissions \& Licensing

Reprints including high resolution figures, can be found at: http://n.neurology.org/content/82/20/1846.1.full

This article cites 4 articles, 1 of which you can access for free at: http://n.neurology.org/content/82/20/1846.1.full\#ref-list-1

Information about reproducing this article in parts (figures,tables) or in its entirety can be found online at:

http://www.neurology.org/about/about_the_journal\#permissions

Information about ordering reprints can be found online:

http://n.neurology.org/subscribers/advertise

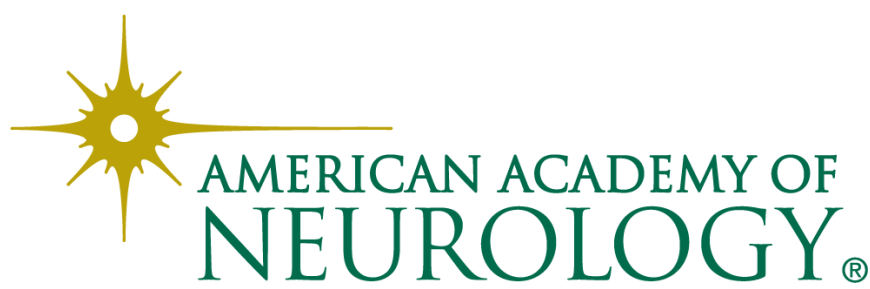

